\title{
China's changing landscape during the 1990s: Large-scale land transformations estimated with satellite data
}

\author{
Jiyuan Liu, ${ }^{1}$ Hanqin Tian, ${ }^{2}$ Mingliang Liu, ${ }^{1,2}$ Dafang Zhuang, ${ }^{1}$ Jerry M. Melillo, ${ }^{3}$ \\ and Zengxiang Zhang ${ }^{4}$
}

Received 30 September 2004; revised 28 November 2004; accepted 21 December 2004; published 27 January 2005.

[1] Land-cover changes in China are being powered by demand for food for its growing population and by the nation's transition from a largely rural society to one in which more than half of its people are expected to live in cities within two decades. Here we use an analysis of remotely sensed data gathered between 1990 and 2000, to map the magnitude and pattern of changes such as the conversion of grasslands and forests to croplands and the loss of croplands to urban expansion. With high-resolution $(30 \mathrm{~m})$ imagery from Landsat TM for the entire country, we show that between 1990 and 2000 the cropland area increased by 2.99 million hectares and urban areas increased by 0.82 million hectares. In northern China, large areas of woodlands, grasslands and wetlands were converted to croplands, while in southern China large areas of croplands were converted to urban areas. The land-cover products presented here give the Chinese government and international community, for the first time, an unambiguous understanding of the degree to which the nation's landscape is being altered. Documentation of these changes in a reliable and spatially explicit way forms the foundation for management of China's environment over the coming decades. Citation: Liu, J., H. Tian, M. Liu, D. Zhuang, J. M. Melillo, and Z. Zhang (2005), China's changing landscape during the 1990s: Large-scale land transformations estimated with satellite data, Geophys. Res. Lett., 32, L02405, doi:10.1029/ 2004GL021649.

\section{Introduction}

[2] Land use represents the most substantial human alteration of the Earth system in the past 300 years [Vitousek et al., 1997]. Between one-third and one-half of the land surface has been transformed [Houghton, 1994; Vitousek et al., 1997; Ramankutty et al., 2002]. China is the world's third largest country, the most rapidly developing nation and home to 1.3 billion people. The unprecedented combination of economic and population growth since the early 1980s has led to a dramatic land transformation across the nation. This large-scale land transformation has important implica-

\footnotetext{
${ }^{1}$ Institute of Geographical Sciences and Natural Resources Research, Chinese Academy of Sciences, Beijing, China.

${ }^{2}$ School of Forestry and Wildlife Sciences, Auburn University, Auburn, Alabama, USA.

${ }^{3}$ The Ecosystems Center, Marine Biological Laboratory, Woods Hole, Massachusetts, USA.

${ }^{4}$ Institute of Remote Sensing Applications, Chinese Academy of Sciences, Beijing, China.
}

Copyright 2005 by the American Geophysical Union. 0094-8276/05/2004GL021649\$05.00 tions for cycles of carbon [Tian et al., 2003], nitrogen [Zheng et al., 2002] and water [Fu, 2003] at regional and global scales.

[3] The drivers of land-cover change in China - a growing population, changes in the amount and type of food consumed, and urbanization - have been gaining strength in recent decades. China's population has grown from about 980 million people in 1980 to almost 1.3 billion people today [State Statistical Bureau (SSB), 2003]. This growth in population has increased the demand for food. In addition, diets of the Chinese people have changed. The consumption of coarse grains and tubers has decreased in favor of more finely milled wheat, rice and animal protein including eggs, chicken and pork [SSB, 1988, 1991, 2001a, $2002,2003]$. While it is clear that these changes in food demand and preference have affected China's landscape, the details of the effects are debated [Brown, 1995; Huang and Rozelle, 1995; Heilig, 1999; Chameides et al., 1999; Houghton and Hackler, 2003; Tian et al., 2003].

[4] China's landscape is also changing as a result of urbanization. China is in transition from a largely rural society to a predominantly urban one. Two decades ago, fewer than $20 \%$ of China's people lived in urban areas; today it is $36 \%$; and by 2020 it is expected to be $60 \%$ [People's Daily, 2001a, 2001b]. There is anecdotal evidence that some of the urban growth is at the expense of prime agricultural land. There are also scattered reports of natural ecosystems, including forests, grasslands and wetlands, being converted to urban areas. To date, there is no reliable nation-wide documentation of the landscape changes associated with urbanization [Heilig, 1999; Frolking et al., 1999; Seto et al., 2000; Houghton and Hackler, 2003; Tian et al., 2003; Xiao et al., 2003]. Here we report the results of the first comprehensive analysis of land-cover changes for all of China during the period 1990 to 2000, based on high resolution remote sensing of Landsat TM/ETM imagery.

\section{Data and Methods}

[5] We used datasets developed by the Chinese Academy of Sciences from Landsat TM scenes with a spatial resolution of $30 \times 30 \mathrm{~m}$. As part of the analysis, we developed a standard methodology for image processing and interpretation [Liu, 1996; Zhuang et al., 1999; Liu and Buheaosier, 2000; Liu et al., 2001]. The database includes timeseries data for three time periods: i) late 1980s, including Landsat-TM scenes for 1987-1990; ii) mid 1990s, including Landsat-TM scenes for 1995/1996; and iii) late 1990s, including Landsat-ETM scenes for 1999/2000. For each time period, we used more than 500 scenes to cover the entire nation (514 TM scenes in late 1980s, 520 TM scenes 
Table 1. Changes in Land Cover at National Scale During 19902000 (Unit: 1000 ha)

\begin{tabular}{crrrrr}
\hline Land Cover & \multicolumn{7}{c}{$\begin{array}{c}\text { \% of Total } \\
\text { Land Area } \\
\text { Types }\end{array}$} & \multicolumn{7}{c}{ for 2000 } & Change & \% Change \\
\hline Cropland & $138,152.3$ & $141,144.2$ & 14.85 & $+2,991.9$ & +2.17 \\
Paddy & $35,508.9$ & $35,650.2$ & 3.75 & +141.3 & +0.40 \\
Dryland & $102,643.4$ & $105,494.0$ & 11.10 & $+2,850.6$ & +2.78 \\
Woodland & $227,827.8$ & $226,738.3$ & 23.86 & $-1,089.5$ & -0.48 \\
Forests & $138,314.4$ & $137,595.5$ & 14.48 & -718.9 & -0.52 \\
Grassland & $306,356.3$ & $302,919.5$ & 31.88 & $-3,436.8$ & -1.12 \\
Water body & $32,762.0$ & $32,922.0$ & 3.46 & +160.0 & +0.49 \\
Built-up & $44,670.6$ & $46,430.1$ & 4.89 & $+1,759.5$ & +3.94 \\
$\quad$ Urban & $3,322.2$ & $4,145.4$ & 0.44 & +823.2 & +24.78 \\
Unused land & $200,501.9$ & $200,121.7$ & 21.06 & -380.2 & -0.19 \\
\hline
\end{tabular}

in mid 1990s and 512 ETM scenes in late 1990s). These Landsat-TM/ETM images were geo-referenced and orthorectified, using field-collected ground control points and high-resolution digital elevation models. The mean location errors for TM geo-correction are less than 1.5 pixels (i.e., 45 meters). Visual interpretation and digitization of TM images at the scale of 1:100,000 were done to generate thematic maps of land cover under technical support from Intergraph MGE (Modular GIS Environment) software [Zhuang et al., 1999]. A hierarchical classification system of 25 land-cover classes was applied to the data. The 25 classes of land cover were grouped further into 6 aggregated classes of land cover - croplands, woodlands, grasslands, water bodies, unused land and built-up areas including urban areas (Table 1).

[6] The cropland areas for all three time periods (late 1980s, mid 1990s and late 1990s) were adjusted to account for the fraction of sub-pixel non-cropland area. To do this, we established a stratified multi-layer sampling design that divided China into 870 sampling zones to account for features in cropland areas (e.g., roads and pathways, small rice paddy levees and irrigation channels). For each sampling zone, we used a large number of aerial photos and line feature maps such as roads, railways and rivers for the year of 1995 to develop adjustment factors for the same year, and then applied these adjustment factors to the other two time periods. After the adjustment of cropland area, the areas of build-up, water body and woodland at national scale have increased by $267 \%, 121 \%$ and $102 \%$ separately [Zhang et al., 2000].

[7] The interpretation of TM images and land-cover classifications was validated against extensive field surveys. During 1999 and 2000, for example, we conducted ground truth checking for more than $75,000 \mathrm{~km}$ of transects across China and more than 8,000 field photos were taken using cameras equipped with global position systems (GPS). We did not take field photos and out-door survey in the late 1980s and the middle 1990s, but evaluated TM-based classification against historical records including aerial photo and tabular data in a large number of field sites and interviewed with many local people as well as experts to test the validity of our interpretations. To evaluate interpretation accuracy of land cover change over the two time periods, we checked land cover change for 364,379 field sites distributed in 2,158 counties across China. The average interpretation accuracy is $92.9 \%$ for land cover classification and $97.6 \%$ for land-cover change detection. This high accuracy value of land-cover classification is mainly because of the manual interpretation of Landsat TM imagery for land cover classification in China. Compared to unsupervised clustering method based on spectral character of land surface, the manual interpretation of Landsat TM imagery is labor intensive and time consuming. The database from 1999/2000 was used for our analysis of current patterns of land cover in China. By comparing land cover patterns between the late 1980s and the late 1990s, we

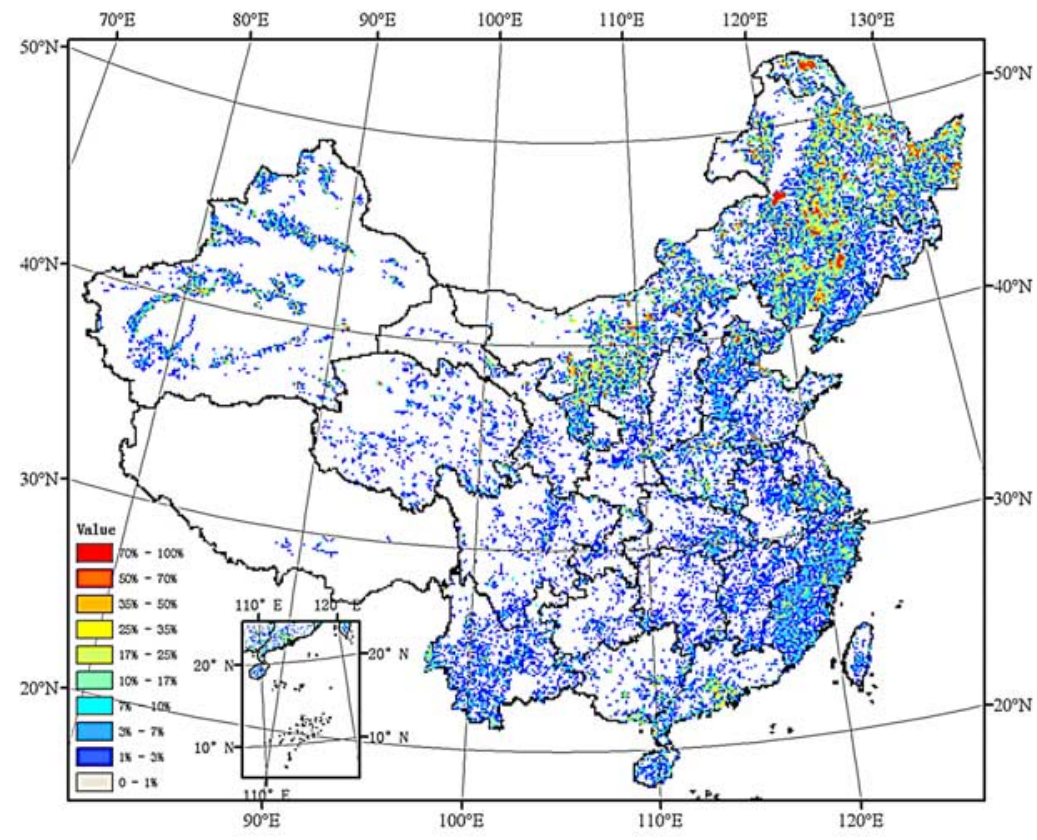

Figure 1. Intensity of land transformations across China. Legend value indicates the intensity of land transformations within a grid cell of $10 \times 10 \mathrm{~km}$, i.e., the percentage of transformed land in the grid cell. 
Table 2. Changes in Land Cover at Provincial and Regional Scales During 1990-2000 (Unit: 1000 ha)

\begin{tabular}{|c|c|c|c|c|c|c|}
\hline \multirow{2}{*}{$\begin{array}{c}\text { Province } \\
\text { Region }\end{array}$} & \multicolumn{6}{|c|}{ Type } \\
\hline & Cropland & Woodland & Grassland & Water Body & Built-Up & Unused \\
\hline Shannxi & +14.4 & +20.0 & +61.3 & -5.5 & +38.7 & -128.8 \\
\hline Gansu & +77.6 & -34.2 & -36.0 & -5.1 & +26.1 & -28.3 \\
\hline Qinghai & +26.2 & -2.0 & -44.4 & -14.0 & +8.6 & +25.6 \\
\hline Ningxia & +223.9 & +10.1 & -236.7 & +0.1 & +11.8 & -9.2 \\
\hline Xinjiang & +392.7 & +18.4 & -685.0 & +80.6 & +68.4 & +124.9 \\
\hline Northwest & +734.9 & +12.3 & -940.8 & +56.1 & +153.4 & -15.9 \\
\hline Beijing & -93.9 & +11.8 & -7.0 & +11.4 & +77.7 & 0.0 \\
\hline Tianjin & -21.2 & -0.1 & -1.8 & +12.1 & +8.7 & -0.8 \\
\hline Hebei & -175.7 & -2.6 & -32.3 & -14.1 & +233.7 & -13.3 \\
\hline Shanxi & +4.1 & -28.2 & -1.4 & -5.4 & +30.8 & +0.2 \\
\hline Inner Mongolia & +1122.4 & -104.9 & -1204.3 & +26.9 & +12.9 & +147.1 \\
\hline Shandong & -127.7 & +1.4 & -7.9 & +61.1 & +157.9 & -95.4 \\
\hline Henan & +9.6 & +10.0 & -80.8 & -49.5 & +119.6 & -8.9 \\
\hline North & +717.5 & -112.7 & -1335.4 & +42.6 & +641.2 & +28.9 \\
\hline Liaoning & +208.3 & -205.3 & -23.6 & -2.5 & +42.5 & -15.7 \\
\hline Jilin & +424.3 & +36.3 & -364.8 & -71.5 & +16.1 & -40.4 \\
\hline Heilongjiang & +1811.5 & -837.7 & -590.1 & -62.3 & +13.4 & -334.8 \\
\hline Northeast & +2444.1 & -1006.7 & -978.5 & -136.3 & +71.9 & -390.8 \\
\hline Chongqing & -21.4 & +1.9 & -3.4 & +0.2 & +22.7 & 0.0 \\
\hline Sichuan & -54.7 & -88.4 & +66.4 & +10.4 & +66.7 & -0.3 \\
\hline Guizhou & +38.1 & -81.3 & +32.4 & +2.3 & +8.4 & +0.1 \\
\hline Yunnan & -46.0 & -46.4 & +64.2 & +2.1 & +25.9 & 0.0 \\
\hline Tibet & -0.9 & +12.3 & -8.1 & -4.9 & +1.6 & -0.0 \\
\hline Southwest & -84.9 & -201.8 & +151.4 & +10.2 & +125.3 & -0.2 \\
\hline Hubei & -62.8 & -15.9 & +2.7 & +31.6 & +37.8 & +6.7 \\
\hline Hunan & -35.7 & -8.9 & -4.8 & +23.1 & +26.1 & +0.2 \\
\hline Guangdong & -185.4 & -3.6 & -18.9 & +58.2 & +158.4 & +0.2 \\
\hline Guangxi & +15.8 & +1.3 & -59.3 & +19.6 & +34.5 & 0.0 \\
\hline Hainan & -9.6 & +16.7 & -22.1 & +3.1 & +13.4 & -3.2 \\
\hline South & -277.8 & -10.3 & -102.3 & +135.6 & +270.2 & +3.8 \\
\hline Shanghai & -41.8 & -0.2 & -3.9 & +5.3 & +40.6 & 0.0 \\
\hline Jiangsu & -246.6 & -4.2 & -28.4 & +41.3 & +238.2 & -0.3 \\
\hline Zhejiang & -112.3 & +37.5 & +12.2 & -1.1 & +66.2 & -2.5 \\
\hline Anhui & -98.9 & -19.7 & +6.8 & +2.4 & +109.3 & 0.0 \\
\hline Fujian & -18.2 & +189.1 & -188.9 & -0.5 & +21.3 & -2.8 \\
\hline Jiangxi & -20.8 & +23.8 & -25.2 & +4.5 & +18.2 & -0.5 \\
\hline Taiwan & -3.2 & +3.5 & -3.9 & -0.1 & +3.7 & +0.1 \\
\hline East & -541.8 & +229.8 & -231.2 & +51.9 & +497.4 & -6.0 \\
\hline
\end{tabular}

determined a decade of change in land cover for the entire nation. Additional details about the methodology we used to generate the databases of land cover from Landsat TM have been documented in other sources [Liu, 1996; Zhuang et al., 1999; Liu and Buheaosier, 2000; Liu et al., 2001].

\section{Results and Discussion}

[8] China's landscape underwent large changes during the period 1990 to 2000 (Figure 1 and Table 1). About 12.8 Mha experienced changes in land cover during this period. Almost $80 \%$ of these changes occurred in the four regions making up the eastern half of China (Table 2).

[9] Changes in the area and location of croplands were evident from our analysis. The area of croplands was 141 Mha in 2000; a net increase of almost 3 Mha or about $2.2 \%$ over the decade of the $1990 \mathrm{~s}$. During this time, about 3.2 Mha of croplands were converted to other land covers including 1.5 Mha to urban land, while about 6.2 Mha, mostly woodlands, grasslands and previously unused lands, were converted to croplands (Table 3).

[10] The amount of land moving into and out of croplands varied across China. Large gains in croplands occurred in Northeast China at the expense of woodlands and grasslands (Table 2). This land transformation is particularly obvious in Heilongjiang province. Cropland area also increased in the North and Northwestern regions, mostly through the conversion of grasslands. For example, the conversion from grasslands to croplands dominated the land transformation in Inner Mongolia. Across the southern

Table 3. Land Transformation Matrix at National Scale During 1990-2000 (Unit: 1000 ha)

\begin{tabular}{lrrrrrr}
\hline & \multicolumn{7}{c}{ To } \\
\cline { 2 - 6 } \multicolumn{1}{c}{ From } & Cropland & Woodland & Grassland & Water Body & Built-Up & Unused Land \\
\hline Cropland & & 515.9 & 641.7 & 364.3 & 1509.0 & 134.2 \\
Woodland & 1746.8 & & 811.2 & 40.2 & 93.0 & 28.4 \\
Grassland & 3456.8 & 1047.0 & & 150.4 & 76.6 & 914.1 \\
Water body & 285.8 & 25.4 & 91.6 & & 39.8 & 178.9 \\
Built-up & 8.6 & 2.0 & 3.6 & 1.9 & & 0.0 \\
Unused land & 658.7 & 40.1 & 659.9 & 228.0 & 49.0 & \\
\hline
\end{tabular}


half of China, in the regions designated as East, South and Southwest, cropland area decreased during the 1990s.

[11] Urbanization was the cause of major land-cover changes during the last decade of the 20th century in China. In this 10-year period, the urban landscape grew by almost $25 \%$, from about $3,322,000$ ha to about $4,145,000$ ha. The rate of urbanization differed among regions across China, with about one third of the increase occurring in the North region, and almost another third occurring in the East region (Table 2). There is an obvious crescent of urbanization during the 1990s that runs from Beijing to Shanghai.

[12] By the end of the 20th century, we estimate that woodlands occupied about 230 Mha. There was a net loss of about 1.1 Mha of woodland in the 1990s (Table 1). The largest loss of woodlands occurred in the Northeast region, where they were mostly converted to croplands (Table 2). Forests are the largest subclass within the woodlands category. Our classification of forests includes natural and planted forests with canopy coverage greater than $30 \%$. We estimated that forests covered about 137.6 Mha in 2000, down by 0.7 Mha or $0.52 \%$ over the decade of the $1990 \mathrm{~s}$.

[13] Grasslands sustained the greatest losses of the natural ecosystems (Table 1). Our data shows a net loss of 3.4 Mha of grassland area in the decade of the 1990s, going from about 306.3 Mha to about 302.9 Mha. The conversion of grasslands to croplands accounted for most to the change (Table 3 ). These changes occurred primarily in five provinces: Ningxia and Xinjiang in the Northwest; Inner Mongolia in the North; and Heilongjiang and Jilin in the Northeast (Table 2).

[14] For many of the land-cover categories, the estimates of total areas and changes in them over the 1990s based on remote sensing differ from those reported by other Chinese government sources based on surveys using other techniques. For example, our estimate of cropland area for 1995 (about 140 Mha) is almost 50\% larger than the State Statistical Bureau's estimate [State Land Administration (SLA), 1996], and about 8\% larger than the State Land Administration's estimate [SLA, 1996]. An estimate of urban area in China has been particularly problematic in China. According to State Statistical Bureau [SSB, 2001b], at the end of 2000, urban area was 1622.1 thousand ha, which is about $60 \%$ lower than our Landsat-TM based estimate of 4145.4 thousand ha. With respect to forests, this study shows a net decrease in forest area during the 1990s, while the State Administration of Forestry reports an increase in forest area [State Forestry Administration, 1989, 1994, 1999].

[15] Uncertainty exists in our analysis of land transformations across China. Although the average location errors of TM images are less than 45 meters, the small errors could bias our detection of land transformations. Uncertainty also arises from the lack of direct ground truth in the late 1980s and the middle 1990s.

[16] However, we are confident that our estimates of land cover and land-cover change are a significant improvement over other earlier estimates. These new estimates should improve the ability of policy makers to manage China's environment as the nation transitions to sustainability. Improved estimates of cropland areas and changes in them over time will permit better planning for meeting the food needs of the world's largest population. Improved estimates of forest and grassland areas and changes in them over time will enable better estimates of net carbon balance across China. Improved estimates of wetland areas and changes in them over time will sharpen the planning for the conservation for this critical wildlife habitat. In summary, repeated land cover inventories of China based on remote sensing, such as the ones presented here, will assist in the harmonization of economic growth and environmental protection and improvement.

[17] Acknowledgments. This work has been supported by the Key Project of National Science Foundation of China (90202002), Ministry of Science and Technology (MOST) 973 Program (2002CB412500), the Key Knowledge Innovation Project of the Chinese Academy of Sciences K2CX2-308), NASA Interdisciplinary Science Program (NNG04GM39C), National Science Foundation of China (40128005). We would like to thank Xiubin Li, Jikun Huang, Karen Seto, Yaoqi Zhang, and two anonymous reviewers for their critical comments.

\section{References}

Brown, L. R. (1995), Who Will Feed China?: Wake-Up Call for a Small Planet, W. W. Norton, New York.

Chameides, W. L., et al. (1999), Is ozone pollution affecting crop yields in China?, Geophys. Res. Lett., 26, 867-870.

Frolking, S., X. Xiao, Y. Zhuang, W. Salas, and C. Li (1999), Agricultural land-use in China: A comparison of area estimates from ground-based census and satellite-borne remote sensing, Global Ecol. Biogeogr., 5, $407-416$.

Fu, C. (2003), Potential impacts of human-induced land cover change on East Asia monsoon, Global Planet. Change, 37, 219-229.

Heilig, G. K. (1999), ChinaFood: Can China Feed Itself? [CD-ROM, version 1.1], Int. Inst. for Appl. Syst. Anal., Laxenburg, Austria, available at http://www.iiasa.ac.at/Research/LUC/ChinaFood/index_m.htm.

Houghton, R. A. (1994), The worldwide extent of land-use change, BioScience, 44, 305-312.

Houghton, R. A., and J. L. Hackler (2003), Sources and sinks of carbon from land-use change in China, Global Biogeochem. Cycles, 17(2), 1034, doi:10.1029/2002GB001970.

Huang, J. K., and S. Rozelle (1995), Environmental stress and grain yields in China, Am. J. Agric. Econ., 77, 853-864.

Liu, J. (1996), Macro-Scale Survey and Dynamic Study of Natural Resources and Environment of China by Remote Sensing (in Chinese), China Sci. and Technol. Press, Beijing.

Liu, J., and Buheaosier (2000), Study on spatial-temporal feature of modern land-use change in China: Using remote sensing techniques (in Chinese), Quat. Sci., 20(3), 229.

Liu, M., X. Tang, J. Liu, and D. Zhuang (2001), Research on scaling effect based on $1 \mathrm{~km}$ grid cell data (in Chinese), J. Remote Sens., 5(3), 183-189.

People's Daily (2001a), China's urbanization rate to reach $60 \%$ in 20 years, 17 May, available at http://english.people.com.cn/english/200105/17/ eng20010517 70205.html.

People's Daily (2001b), China's urbanization rate reaches 36 percent: Minister, 7 June, available at http://english.people.com.cn/english/ 200106/07/eng20010607 72017.html.

Ramankutty, N., J. Foley, and N. J. Olejniczak (2002), People on the land: Changes in global population and croplands during the 20th century, Ambio, 31, 251-257.

Seto, K. C., R. K. Kaufman, and C. E. Woodcock (2000), Landsat reveals China's farmland reserves, but they're vanishing fast, Nature, $406,121$.

State Forestry Administration (1989), Forest Resources Statistics of China for Period 1984-88 (in Chinese), Dep. of For. Resour. and Manage., Beijing, China.

State Forestry Administration (1994), Forest Resources Statistics of China for Period 1989-1993 (in Chinese), Dep. of For. Resour. and Manage., Beijing, China.

State Forestry Administration (1999), Forest Resources Statistics of China for Period 1994-1998 (in Chinese), Dep. of For. Resour. and Manage., Beijing, China.

State Land Administration (SLA) (1996), Summary of national land use during the eighth five-year plan (in Chinese), Dep. for Plann. and Finan., Beijing, China.

State Statistical Bureau (SSB) (1988), China Statistical Yearbook (in Chinese), China Stat. Press, Beijing.

State Statistical Bureau (SSB) (1991), China Statistical Yearbook (in Chinese), China Stat. Press, Beijing. 
State Statistical Bureau (SSB) (2001a), China Statistical Yearbook (in Chinese), China Stat. Press, Beijing.

State Statistical Bureau (SSB) (2001b), Urban Statistical Yearbook of China (in Chinese), China Stat. Press, Beijing.

State Statistical Bureau (SSB) (2002), China Statistical Yearbook (in Chinese), China Stat. Press, Beijing.

State Statistical Bureau (SSB) (2003), China Population Statistical Yearbook 2002 (in Chinese), China Stat. Press, Beijing.

Tian, H. Q., J. M. Melillo, D. W. Kicklighter, S. Pan, J. Liu, A. D. McGuire, and B. Moore III (2003), Regional carbon dynamics in monsoon Asia and its implications to the global carbon cycle, Global Planet. Change, 37, 201-217.

Vitousek, P. M., H. A. Mooney, J. Lubchenco, and J. M. Melillo (1997), Human domination of Earth's ecosystems, Science, 277, 494-499.

Xiao, X., J. Liu, D. Zhuang, S. Frolking, S. Boles, B. Xu, M. Liu, W. Salas, B. Moore, and C. Li (2003), Uncertainties in estimates of cropland area in China: A comparison between an AVHRR-derived dataset and a Landsat TM-derived dataset, Global Planet. Change, 37, $297-306$
Zhang, W., D. Zhuang, and W. Hu (2000), Area summarization in establishing the national resources and environmental database (in Chinese), J. Remote Sens., 4, 304-310.

Zheng, X., C. Fu, X. Xu, X. Yan, Y. Huang, S. Han, F. Hu, and G. Chen (2002), The Asian nitrogen cycle case study, Ambio, 31, 79-87.

Zhuang, D., J. Liu, and M. Liu (1999), Research activities on land use/land cover in the past ten years in China using space technology, Chin. Geogr. Sci., 9, 330-334

J. Liu, M. Liu, and D. Zhuang, Institute of Geographical Sciences and Natural Resources Research, Chinese Academy of Sciences, Beijing 100101, China.

J. M. Melillo, Ecosystems Center, Marine Biological Laboratory, Woods Hole, MA 02543, USA.

H. Tian, School of Forestry and Wildlife Sciences, Auburn University, Auburn, AL 36849, USA. (tianhan@auburn.edu)

Z. Zhang, Institute of Remote Sensing Applications, Chinese Academy of Sciences, Beijing 100101, China. 